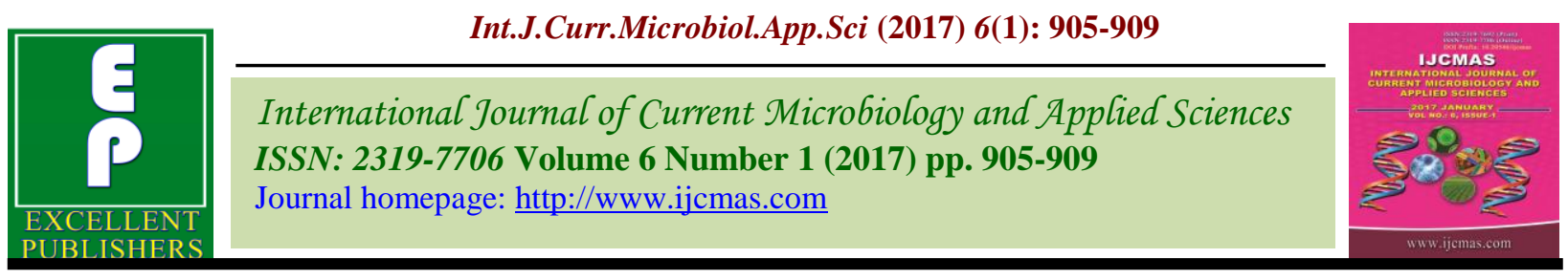

Original Research Article

http://dx.doi.org/10.20546/ijcmas.2017.601.106

\title{
In vitro Efficacy of Fungal and Bacterial Antagonists against Fusarium oxysporum f. sp. ciceri causing Chickpea Wilt
}

\author{
D.S. Thaware*, O.D. Kohire and V.M. Gholve \\ Department of Plant Pathology, Ratnai College of Agriculture, Akluj, Solapur, \\ Maharashtra, India-413 101 \\ *Corresponding author
}

\section{A B S T R A C T}

Keywords

Fusarium wilt, chickpea losses, fungal antagonistic, mycelial inhibition.

Article Info

Accepted: 28 December 2016 Available Online: 10 January 2017
Fusarium oxysporum f. sp. ciceri is one of the most destructive pathogen, causing wilt disease in chickpea and thereby inflicting accountable quantitative (48.29\%) as well as qualitative losses. All the six fungal and two bacterial bioagents tested in vitro, exhibited significant mycelial growth inhibition of Fusarium oxysporum f. sp. ciceri. However, Trichoderma viride recorded significantly highest mycelial growth inhibition (75.55\%), followed by Trichoderma harzianum (73.77\%) Trichoderma koningii (71.88\%) and Pseudomonas fluorescens (43.77\%). Rest of the bioagents tested also caused significant mycelial inhibition of the test pathogen.

\section{Introduction}

Chickpea (Cicer arietinum L.) is an important pulse crop, which belongs to leguminoceae family, ranking third after dry beans (Phaseolus vulgaris L.) and dry peas (Pisum sativum L.) The centre of origin of chickpea is in Eastern Mediterranean (Aykoid and Doughty, 1964). The Kabuli and Desi chickpea is grown throughout the world with different names i.e. Chickpea (UK), Garbanzo (Latin America), Bengal gram (India), Hommes Hamaz (Arab world), Shimbra (Ethiopia) and Nohud and Loblebi (Turkey). India is largest producer of chickpea in world sharing 65.25 per cent in area and 65.49 per cent in production. In India, chickpea is grown on 10.23 million ha area with production 9.88 million tonnes and productivity $967 \mathrm{~kg} / \mathrm{ha}$. The production of chickpea in Maharashtra is 1.62 million tonnes with productivity $891 \mathrm{~kg} / \mathrm{ha}$ which covered nearly 1.82 million ha of area. Maharashtra contributes about 16.42 per cent share in total production of country (Anonymous, 2014).

The major limiting factor in chickpea production is Fusarium wilt which is caused by $F$. oxysporum Schlechtend. Fr. f. sp. ciceris (Padwick) Matuo and K. Sato (Jalali and Chand, 1992; Haware, 1990 and Nene 
and Reddy, 1987). It was first reported in Indo-Pak sub-continent (Butler, 1918). McRae (1932) as well as Prasad and Padwick (1939) reported $F$. oxysporum f. sp. ciceris pathogenic to chickpea crop which is now accepted worldwide as the causal agent of ciceri spp. In general, the disease causes substantial yield losses which may reach even 100 per cent under favourable weather conditions (Jalali and Chand, 1992). The chickpea is cultivated as a rain fed crop in Maharashtra state and yield losses amounted to 10 to 15 per cent (Khillare et al., 2009).

\section{Materials and Methods}

\section{Dual culture technique}

Six fungal antagonists viz., Trichoderma viride, T. harzianum, T. hamatum, T. virens, T. koningii, Aspergillus nigar and two bacterial antagonists viz., Pseudomonas fluorescens and Bacillus subtilis were evaluated in vitro against Fusarium oxysporum f. sp. ciceri, applying Dual culture technique (Dennis and Webster, 1971). Seven days old culture of the test bioagents and the test pathogen (Fusarium oxysporum f. sp. ciceri) were used for the study. Culture discs (7 mm dia.) of the test pathogen and bioagents (7 mm diameter) were cut out with sterilized cork borer. Then two culture discs, one each of the test fungus and bioagent were placed aseptically at equidistance and exactly opposite with each other on solidified PDA medium in Petri plates and plates were incubated at $28 \pm 2{ }^{0} \mathrm{C}$. Three plates / treatment / replication were maintained. PDA plates inoculated only with culture disc of the test pathogen were maintained as untreated control. The different tretements were taken up for testing the bioefficacy of detailed as below.

$\begin{array}{ll}\text { Tr. No. } & \text { Treatments details } \\ \mathrm{T}_{1} & \text { Trichoderma viride } \\ \mathrm{T}_{2} & \text { Trichoderma harzianum } \\ \mathrm{T}_{3} & \text { Trichoderma koningii } \\ \mathrm{T}_{4} & \text { Trichoderma hamatum } \\ \mathrm{T}_{5} & \text { Trichoderma virens } \\ \mathrm{T}_{6} & \text { Aspergillus niger } \\ \mathrm{T}_{7} & \text { Pseudomonas fluorescens } \\ \mathrm{T}_{8} & \text { Bacillus subtilis } \\ \mathrm{T}_{9} & \text { Control (untreated) }\end{array}$

Observations on linear mycelial growth of the test pathogen and bioagent were recorded at an interval of 24 hours and continued till untreated control plates were fully covered with mycelial growth of the test pathogen. Per cent inhibition of the test pathogen by the bioagent over untreated control was calculated by applying following formula (Arora and Upaddhyay, 1978).

Linear mycelial growth in - Linear mycelial growth in control plate intersecting plate

$\begin{aligned} & \text { Per cent growth } \\ & \quad \text { inhibition }\end{aligned}$
Linear mycelial growth in control plate 


\section{Results and Discussion}

The results obtained on mycelial growth and inhibition of Fusarium oxysporum f. sp. ciceri with six fungal and two bacterial antagonists are presented in Table 1. Results revealed that all the bioagents evaluated, exhibited fungistatic/antifungal activity against Fusarium oxysporum f. sp. ciceri and significantly inhibited its growth over untreated control.

Table.1 In vitro bioefficacy of bioagents on mycelial growth and inhibition of Fusarium oxysporum f. sp. Ciceri

\begin{tabular}{clcc}
\hline $\mathbf{T r}$. & \multicolumn{1}{c}{ Treatments details } & $\begin{array}{c}\text { *Growth of the } \\
\text { pathogen }(\mathbf{m m})\end{array}$ & $\begin{array}{c}\text { Average } \\
\text { inhibition }(\%)\end{array}$ \\
$\mathrm{T}_{1}$ & Trichoderma viride & 22.00 & 75.55 \\
& & & $(60.36)$ \\
$\mathrm{T}_{2}$ & Trichoderma harzianum & 23.60 & 73.77 \\
& & & $(59.19)$ \\
$\mathrm{T}_{3}$ & Trichoderma koningii & 25.30 & 71.88 \\
& & & $(57.97)$ \\
$\mathrm{T}_{4}$ & Trichoderma hamatum & 27.00 & 70.00 \\
& & 31.30 & $(56.79)$ \\
$\mathrm{T}_{5}$ & Trichoderma virens & 26.30 & 65.22 \\
& & & $(53.86)$ \\
$\mathrm{T}_{6}$ & Aspergillus niger & 50.60 & $(57.77$ \\
& & & 43.77 \\
$\mathrm{~T}_{7}$ & Pseudomonas fluorescens & 52.00 & $(41.42)$ \\
$\mathrm{T}_{8}$ & Bacillus subtilis & & 42.22 \\
& & 90.00 & $(40.52)$ \\
$\mathrm{T}_{9}$ & Control (untreated) & 00.00 \\
\end{tabular}

* Mean of three replications

Figures in parenthesis are arc sine transformed value

Of the six fungal antagonists tested, Trichoderma viride was found most effective and recorded least linear mycelial growth $(22.00 \mathrm{~mm})$ with highest mycelial inhibition (75.55\%) of the test pathogen. The second and third best antagonists found were Trichoderma harzianum and Trichoderma koningii, which recorded mycelial growth of $23.60 \mathrm{~mm}$ and $25.30 \mathrm{~mm}$ and mycelial inhibition of 73.77 and 71.88 per cent, respectively. This was followed by fungal antagonist Aspergillus niger, Trichoderma hamatum and Trichoderma virens were found least effective which recorded 26.30, 27.00 and $31.30 \mathrm{~mm}$ linear mycelial growth and 70.77, 70.00 and 65.22 per cent mycelial inhibition, respectively. The bacterial antagonists Pseudomonas fluorescens and Bacillus subtilis were also found fungistatic and recorded $50.60 \mathrm{~mm}$ and $52.00 \mathrm{~mm}$ linear mycelial growth and 43.77 and 42.22 per cent mycelial inhibition respectively, of the test pathogen.

Thus, all the fungal and bacterial bioagents tested were found fungistatic against Fusarium oxysporum f. sp. ciceri and significantly inhibited its mycelial growth 
over untreated control. However, fungal and bacterial bioagents found most effective in the order of merit were Trichoderma viride, $T$. harzianum, T. koningii, Aspergillus niger, T. hamatum, Trichoderma virens, Pseudomonas fluorescens and Bacillus subtilis.

The effective Trichoderma isolates of present study may be utilizes in combination with other management practices or with other bioagents for enhancing their effect. A few workers have also tested Trichoderma spp. in dual culture against Fusarium oxysporum f. sp. ciceri. Chavan (2004) and Korde (2011) reported that maximum zone inhibition of radial growth of fungus was observed with Trichoderma viride followed by $T$. koningii, T. harzianum, and P. fluorescens. Kapoor et al. (2012) also reported that maximum zone inhibition of radial growth of fungus was observed with Trichoderma viride followed by $T$. harzianum and A. niger. Least zone inhibition was recorded with $T$. virens. Magar, (2012) and Mehta et al., (2012) reported that maximum zone inhibition of radial growth of fungus was observed with Trichoderma viride followed by $T$. harzianum, Aspergillus niger, T. virens and B. subtitis. Yadav, et al., (2014) reported that most effective Trichoderma spp. against Fusarium oxysporum f. sp. ciceri which recorded 71.36 per cent growth inhibition.

The similar results on efficacy of Trichoderma spp. and P. fluorescens were obtained by Sangale and Bambawale, 2004; Srivastava and Mall, 2008; Mulik, 2009; Patil, 2010 and Andrabi et al., 2011.

\section{Acknowledgements}

The authors are thankful to Head, Department of Plant Pathology, Parbhani for funding and providing the valuable suggestions during my research period.

\section{References}

Andrabi, M., Vaid, A. and Kumar, R.V. 2011. Evaluation of different measures to control wilt causing pathogens in chickpea. J. Plant Protection Res., 51(1): 55-59.

Anonymous. 2014. Directorate of Economics and Statistics, Department of Agriculture and Cooperation. Agricultural statistics at a glance, $\mathrm{Pp}$ 94-96.

Arora, D.K. and Upadhyay, R.K. 1978. Effect of fungal staling growth substances on colony interaction. Plant Soil, 49: 685690.

Aykoid, W.R. and Doughty, J. 1964. Legume in human nutrition. FAO nutritional studies, Pp 9.

Butler, E.J. 1918. Fungi and diseases of plants. Book published. (M. C. Saxena, K. B. Singh, edi.), CABI Publishing, CAB Int. Wallingford, UK. Pp 233270.

Chavan, T.B. 2004. Studies on Fusarium oxysporum f. sp. ciceri (Padwick) Snyder and Hansen causing wilt of chickpea (Cicer arietinum L.). M. Sc. (Agri.) thesis submitted to Indira Gandhi Agriculture University, Raipur (India).

Dennis, C. and Webster, J. 1971. Antagonistic properties of species groups of Trichoderma: production of volatile and non-volatile antibiotics. $\mathrm{Tr}$. Br. Mycol. Society, 57: 41-48.

Haware, M.P. 1990. Fusarium wilt and other important diseases of chickpea in the Mediterranean area. Options Mediterr. Ser. Semin., 9: 163-166.

Jalali, B.L. and Chand, H. 1992. Diseases of Cereals and Pulses. (U. S. Singh, A. N. Mukhopadhayay, J. Kumar, and H. S. Chaube, edi.) Prentice Hall, Englewood Cliffs, NY. 1-429-444.

Kapoor, S. Jaiswal, A. and Shukla, D.N. 
2012. Eco-friendly strategies for management of Fusarium wilt of Pisum sativum (L.). African J. Microbiol. Res., 6(48): 7397-7400.

Khilare, V.C., Ahmed, R., Chavan, S.S. and Kohire, O.D. 2009. Management of Fusarium oxysporum f. sp. ciceri by different fungicides. Bioinfolet, 6: 4143.

Korde, M.G. 2011. Studies on Fusarium wilt of chickpea caused by Fusarium oxysporum f. sp. ciceri (Padwik) Synder and Hansan. M. Sc. (Agri.) thesis submitted to VNMKV, Parbhani (India).

Magar, G.S. 2012. Investigation on wilt of chickpea incited by Fusarium oxysporum f. sp. ciceri (Padwick) Snyder and Hansen. M. Sc. (Agri.) thesis submitted to VNMKV, Parbhani (India).

McRae, W. 1932. Report on Imperial Mycologists Science Agriculture Research Institute, Pusa. Pp 31-78.

Mehta, A.N., Chauhan, H.L., Makwana, K.V., Gohel, N.M. and Patel, S.J. 2012. Bioefficacy of phytoextract, antagonist and fungicides against Fusarium udum incitant of pigeonpea wilt. J. Plant Dis. Sci., 5(1): 56-60.

Mulik, M.B. 2009. Studies on wilt of chickpea incited by Fusarium oxysporum f. sp. ciceri (Padwick)
Synder and Hansan. M. Sc. (Agri.) thesis submitted to VNMKV, Parbhani (India).

Nene, Y.L. and Reddy, M.V. 1987. Chickpea diseases and their control. Phytopathol., 42: 499-505.

Patil, V.B. 2010. Studies on survey and management of chickpea wilt in Marathwada region. Ph. D. (Agri.) thesis submitted to VNMKV, Parbhani (India).

Prasad, N. and Padwick, G.W. 1939. The genus Fusarium 11. A species of Fusarium as a cause of wilt of gram $(C$. arietinum L.). Indian J. Agri. Sci., 9: 371-380.

Sangle, U.R. and Bambawale, O.M. 2004. New strains of Trichoderma spp. strongly antagonistic against $F$. oxysporum f. sp. sesami. J. Mycol. Plant Pathol., 34: 181-184.

Srivastava, M. and Mall, T.P. 2008. Efficacy of bio-agents and organic amendments against Fusarium udum causing wilt of pigeonpea. Annual Plant Protection Sci., 16(1): 203-267.

Yadav, S., Mane, S.S. and Ghawade, R.S. 2014. Efficacy of herbicides, fungicides and biological control Agents against chickpea wilt. Punjabrao Deshmukh Krishi Vidhypeeth Res. J., 36(1): 25-28.

\section{How to cite this article:}

Thaware, D.S., O.D. Kohire and Gholve, V.M. 2017. In vitro Efficacy of Fungal and Bacterial Antagonists against Fusarium oxysporum f. sp. ciceri causing Chickpea Wilt. Int.J.Curr.Microbiol.App.Sci. 6(1): 905-909. doi: http://dx.doi.org/10.20546/ijcmas.2017.601.106 